Biol. Stud. 2015: 9(2); 169-180 • DOI: https://doi.org/10.30970/sbi.0902.431

www.http://publications.Inu.edu.ua/journals/index.php/biology

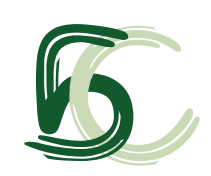

UDC $581.52: 574.34: 574.32$

\title{
TRENDS IN PLANT POPULATION PATTERN CHANGES UNDER NATURAL AND MAN-INDUCED ECOSYSTEM TRANSFORMATIONS OF THE HIGH MOUNTAIN ZONE IN THE UKRAINIAN CARPATHIANS
}

\author{
V. H. Kyyak', V. M. Bilonoha², R. I. Dmytrakh², \\ L. V. Gynda ${ }^{2}$, Y. Y. Nesteruk', V. P. Shtupun ${ }^{2}$ \\ 1'Ivan Franko National University of Lviv, 4, Hrushevskyi St., Lviv 79005, Ukraine \\ ${ }^{2}$ Institute of Ecology of the Carpathians, NAS of Ukraine, 4, Kozelnytska St., Lviv 79026, Ukraine; \\ e-mail: Iusikagynda@gmail.com
}

A substantial increase of area, numbers and density in populations of trees, shrubs and dwarf shrubs - Picea abies, Pinus mugo, Alnus viridis, Juniperus sibirica, Vaccinium-species is marked in the high-mountain zone of the Ukrainian Carpathians. The flowering and fruit maturation at higher elevations of alpine belt are characteristic for the number of species of different life forms: Vaccinium myrtillus, Centaurea mollis, Homogyne alpina, Helictotrichon versicolor, Potentilla aurea. This trend is related to warming and prolongation of growing season and it is peculiar for the species with ecological and climate optima in the forest and subalpine belts, whereas the conditions of the alpine belt are extreme for them. The expanding populations of rare and endemic plant species: Loiseleuria procumbens, Senecio carpaticus, Heracleum carpaticum, Rhododendron myrtifolium, Callianthemum coriandrifolium, Galium pawlowskii have been found. However, the alpine and arctic-alpine species: Oreochloa disticha, Rhodiola rosea, Carex curvula etc. demonstrate negative dynamics. The described processes are mainly the result of successions and plant cover restoration due to grazing termination and climate warming. The impact of plant cover restoration and raising of the timberline on populations of investigated species at high mountain zone of protected areas often cannot be separated from the impact of global warming.

Keywords: plant populations, high mountain zone of the Ukrainian Carpathians, population characteristics, climate change.

\section{INTRODUCTION}

Natural ecosystems of the Ukrainian Carpathians were significantly transformed in the last 20-40 years in response to the land use change and the intensity of humanrelated activity. In $70-80$-ies of $20^{\text {th }}$ century nature reserves were organized. The successions observed after reservation cause the rearrangement of population pattern of many rare and endemic species. In the 90 -ies the grazing and mowing use of mountain meadows and pastures decreased. Simultaneously the recreation impact on mountain

ISSN 1996-4536 (print) • ISSN 2311-0783 (on-line) • Біологічні Студії / Studia Biologica • 2015 • Том 9/№2 • C. 169-180 
ecosystems increased. The main driver of biodiversity transformation among environmental factors is global climate change [9]. It is known that climate change, as well as changes in the character and intensity of human impacts, significantly affect the state of plant populations and vegetation in general. This impact is complex and affects not only the species diversity, relationships between species, but also the basic population parameters of plants. The transformation of habitats can occur under different scenarios and have various consequences [2,6]. Climate change transforms the environments of organisms and populations. Species have to respond to new conditions, adapt through natural selection, or move into suitable habitats $[4,17]$.

Essential achievements on investigation of rare and endemic plant species population pattern and coenotic populations of the most common communities of the high mountain zone of the Ukrainian Carpathians have been made [11, 13-16]. Significant changes took place during the last 5-10 years due to acceleration of changes of abiotic and biotic environmental conditions. The aim of this paper is to find out modern trend of changes in plant population pattern of the high mountain zone of the Ukrainian Carpathians, taking into consideration a set of rare, endemic and common species of different life forms and strategies.

\section{MATERIALS AND METHODS}

The studies were carried out in the Chornohora, Svydovets, Chyvchyny, Marmaros Mts. (Fig. 1) In addition to common species, the populations of rare plants: Antennaria carpatica (Wahlenb.) Bluff et Fingerh., Callianthemum coriandrifolium Reichenb., Dichodon cerastoides (L.) Rchb., Oreochloa disticha (Wulf.) Link, Rhodiola rosea L., Rhododendron myrtifolium Schott et Kotschy, Saxifraga carpatica Sternb., Senecio carpaticus Herbich (RDB) and endemic species: Dianthus carpaticus Woioszcz., Galium pawlowskii Kucowa, Heracleum carpaticum Porc., Pulmonaria filarszkyana Jáv. were the subject of the investigation. Long-term stationary investigations on permanent plots were carried out in the plant species populations. The pattern and variability of these

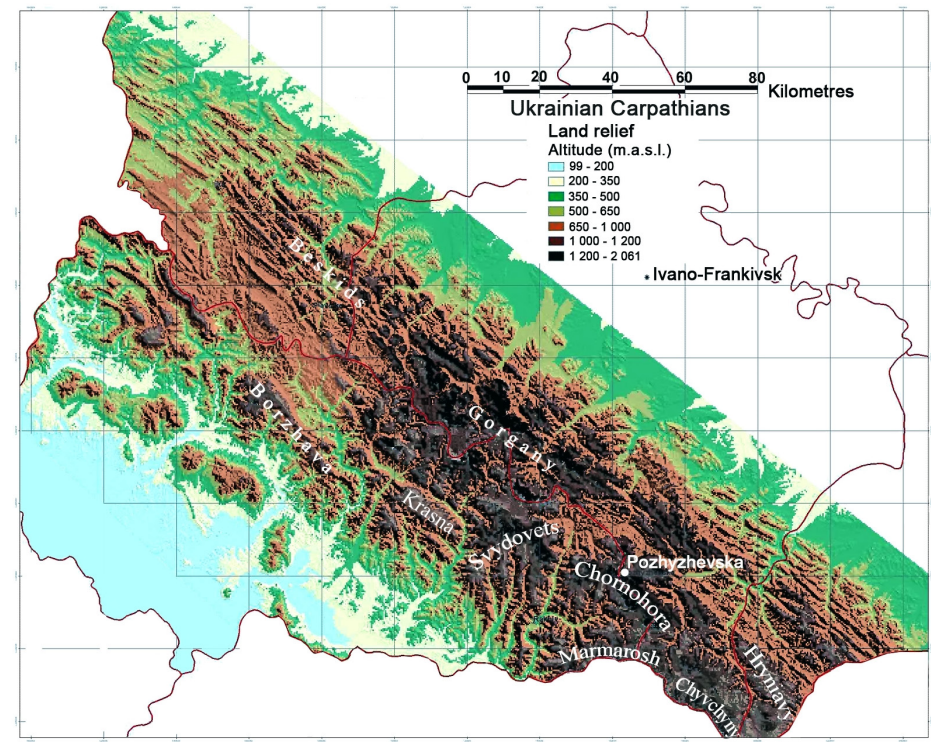

Fig. 1. High mountaine zone of the Ukrainian Carpathians

Рис. 1. Високогірні райони Українських Карпат

ISSN 1996-4536 (print) • ISSN 2311-0783 (on-line) • Біологічні Студії / Studia Biologica • 2015 • Том 9/№2 • C. 169-180 
populations were studied including their numbers, density, spatial distribution, age spectra, vegetative and seed reproduction, viability. Change of these characteristics under the impact of different natural and man-induced drivers, such as climate change, plant cover restoration, grazing, trampling and recreation, were evaluated [13].

\section{RESULTS AND DISCUSSION}

Restoration processes of the large high-mountain territories are currently accompanied by the increasing of area, numbers and density in populations and coenotic populations of trees, shrubs and dwarf shrubs - Picea abies (L.) Karst., Pinus mugo Turra, Alnus viridis (Chaix.) DC., Juniperus sibirica Burgsd., Rhododendron myrtifolium, Vacciniumspecies. This occurs especially rapidly in the subalpine communities, but in the alpine zone, particularly at the altitude 1750-1800 $\mathrm{m}$ a.s.l., the distribution of these species also increased. Successful survival of the Picea abies seedlings and their development at the age of 3-5(8) years at higher elevations up to $1900 \mathrm{~m}$ a.s.l. (Mt. Turkul) was observed.

The shrubs are active at different elevations from timberline to the alpine mountain belt. In the Alnus viridis metapopulation the area of local populations increases especially at the slopes with developed soil profile. In the mesotrophic conditions Alnus viridis colonizes the free sites rapidly and there, where other shrubs already exist, displaces the Pinus mugo brushwood. Area redistribution in favour of Alnus viridis was marked at the timberline and at the lower part of the subalpine belt (1400-1600 m a.s.I.). At these elevations, comparing with other shrub species, thicket of green alder occures on rocky slopes with shallow soil. At the upper part of subalpine belt, in more extreme conditions, the areas of Pinus mugo and Juniperus sibirica have expanded. Within the limits of subalpine belt at 1500-1880 $\mathrm{m}$ a.s.l. these shrubs overgrow the hollows and depressions, which have been formed at the sites with deep snow cover (over $3 \mathrm{~m}$ ) and inhabited by herbal communities. As a consequence of snow depth reduction (Fig. 2) and duration of snowpack such depressions have been colonized by Pinus mugo and Alnus viridis during the last years.

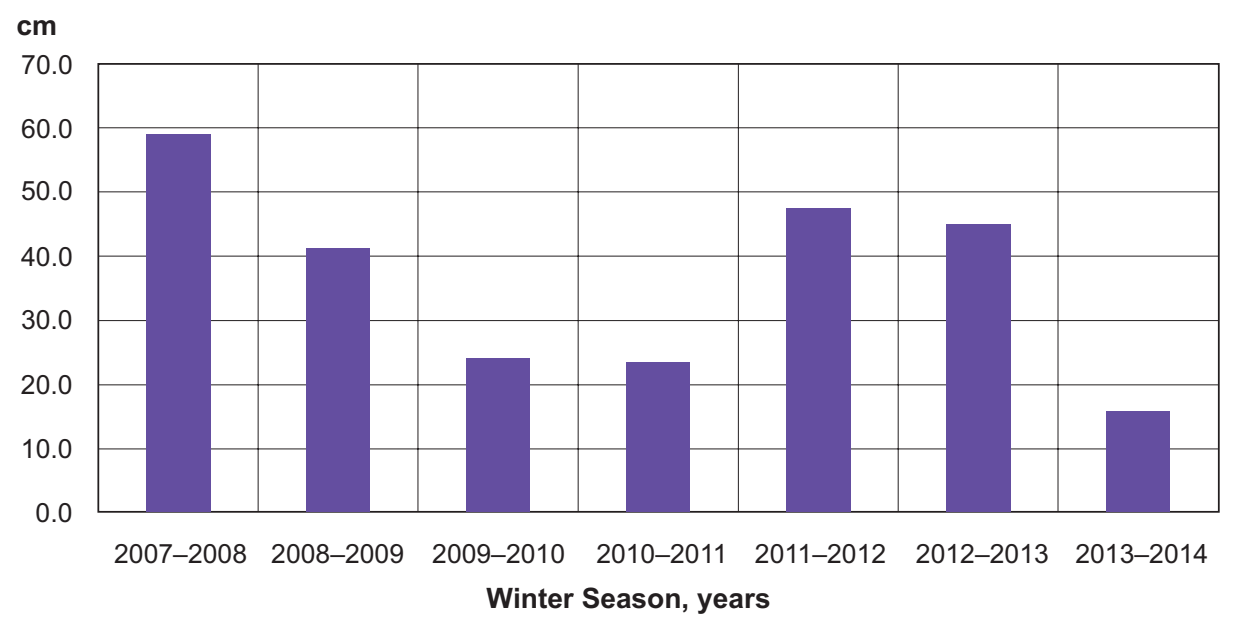

Fig. 2. The average height of snow cover in the environs of high mountain "Pozhyzhevska" biological station (data weather "Pozhyzhevska" of station)

Рис. 2. Середня висота снігового покриву в околицях ВБС “Пожижевська” (дані сніголавинної станції “Пожижевська")

ISSN 1996-4536 (print) • ISSN 2311-0783 (on-line) • Біологічні Студії / Studia Biologica • 2015 • Том 9/№2 • С. 169-180 
On large areas at alpine belt the populations of Ericaceae and Vacciniaceae dwarf shrub species - Rhododendron myrtifolium, Loiseleuria procumbens, Vaccinium myrtilIus L., V. uliginosum L., V. vitis-idaea L., Rhododendron myrtifolium and Vaccinium myrtillus progress most rapidly. The numbers and viability of Rhododendron myrtifolium and Vaccinium myrtillus populations increase on the slopes with different exposition and steepness. At subalpine and alpine belts (1600-1800 m a.s.I.) on convex sites, which are exposed to intensive wind and have a thin snow cover in winter, Vaccinium uliginosum and $V$. vitis-idaea population density and numbers increase. At the summit sites of mountain ranges (1900-2000 m a.s.l.) the area, density and viability of Loiseleuria procumbens populations increase. Juniperus sibirica is the most actively spreading shrub in the alpine zone. For this species seed and vegetative reproduction are combined. Among dwarf shrubs the progress of Vaccinium myrtillus populations is the most intensive. Their density and viability increase because of individual morphometric characteristics such as aboveground phytomass, height and width of individuals, seed productivity. Populations and individual parameters change accordingly. Activation of vegetative and generative reproduction increases cover, area, density and numbers of the mentioned species. Meanwhile, the percentage of flowering individuals grows in population age spectra, as well as their phytomass and seed production. Therefore, seed productivity and yield of seeds of Rhododendron myrtifolium at the alpine belt have particularly increased during the last years. Flowering and fruit maturation of Vaccinium myrtillus have reached more and more higher altitude at the alpine belt within the last decade. This is also characteristic for herbaceous species Centaurea mollis Waldst. et Kit., Homogyne alpina (L.) Cass., Helictotrichon versicolor (Vill.) Pilg., Potentilla aurea L., due to warming (Fig. 3) and prolongation of growing season [5, 11, 12].

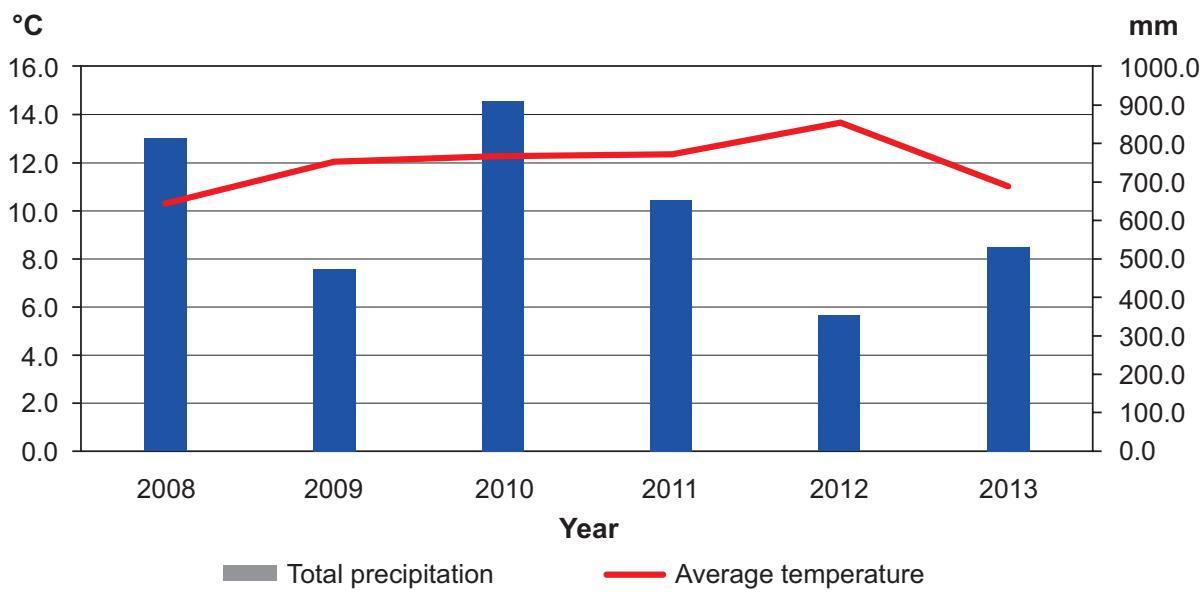

Fig. 3. The average temperature and total precipitation in the growing season (June-September) (data weather of "Pozhyzhevska" station)

Рис. 3. Середня температура повітря та сума опадів у вегетаційний період (червень-вересень) (дані сніголавинної станції “Пожижевська”)

The ecological and climate optima of these species are at the forest or subalpine belt, while the conditions of the alpine belt are extreme. There are substantial shifts in the positions of herbaceous species in the structure of plant communities. In the most spread alpine communities of the Ukrainian Carpathians, where Juncus trifidus L., Festuca 
airoides Lam., Vaccinium uliginosum, Rhododendron myrtifolium, Sesleria coerulans Friv. and Carex curvula All. dominate, as a result of plant cover restoration the density of Festuca supina, Deschampsia cespitosa (L.) P. Beauv. and Carex curvula decreases. This concerns also some low competitive species - Helictotrichon versicolor (Vill.) Pilg., Homogyne alpine (L.) Cass., Campanula alpina Jacq. Colonization of new patches in the alpine belt by Juniperus sibirica is followed by Calamagrostis villosa (Chaix.) J.F. Gmel. growing density.

Arctic-alpine species. The range of the Red Data Book (RDB) species Loiseleuria procumbens in the Chornohora mountain ridge is expanding, 2 new localities (Mts. Breskul, Drabyny) were marked at a distance of 2 and $5 \mathrm{~km}$ from the nearest populations. Foundation of populations is probably observed at these localities. Moreover, the metapopulation of Loiseleuria procumbens of central and south part of Chornohora was noted for considerable increase of numbers, density and variability of local populations, especially on the Mts. Shpytsi, Gutyn and Brebeneskul.

Positive dynamics is observed in young isolated Senecio carpaticus population (RDB), Carpathian-Balkan species, which appeared about 25 years ago in Chornohora, $5 \mathrm{~km}$ from the nearest one on Mt. Rebra after the establishment of reserve and termination of sheep grazing. It is possible to consider the foundation of population was successful: area occupied $-20 \mathrm{~m}^{2}$, total numbers of individuals ca. 340 (see Table), effective number - 90-120 individuals. Active expansion of population area through efficient seed and vegetative reproduction is observed.

Number and density of populations with different land use regime Чисельність і щільність популяцій за різних режимів використання

\begin{tabular}{|c|c|c|c|}
\hline $\begin{array}{l}\text { Species, habitat, } \\
\text { altitude } \mathrm{m} \text { a.s.I. exposition }\end{array}$ & Land use regime & $\begin{array}{l}\text { Density, } \\
\text { individuals } / \mathrm{m}^{2}\end{array}$ & $\begin{array}{l}\text { Number of individuals } \\
\text { in isolated populations }\end{array}$ \\
\hline $\begin{array}{l}\text { Heracleum carpaticum } \\
\text { Dantser, } 1700, \mathrm{E} \\
\text { Preluchny, 1470, SE } \\
\text { Chyvchyn,1600-1700, SE } \\
\text { Palenytsia, 1710, NE } \\
\text { V. Rehieska, 1480, NE }\end{array}$ & $\begin{array}{l}\text { Reservation } \\
\text { Grazing } \\
\text { Grazing } \\
\text { Grazing } \\
\text { Restoration of } \\
\text { vegetation cover }\end{array}$ & $\begin{array}{c}0.02 \pm 0.001 \\
0.2 \pm 0.02 \\
0.01 \pm 0.001 \\
1.2 \pm 0.1 \\
2.5 \pm 0.2\end{array}$ & $\begin{array}{c}280 \\
100 \\
250 \\
240 \\
7000\end{array}$ \\
\hline $\begin{array}{l}\text { Loiseleuria procumbens } \\
\text { Gutyn-Tomnatyk, 1950, E } \\
\text { Shpytsi, 1850, NE }\end{array}$ & $\begin{array}{l}\text { Grazing } \\
\text { Trampling }\end{array}$ & $\begin{array}{l}3.6 \pm 0.4 \\
0.7 \pm 0.1\end{array}$ & $\begin{array}{l}\text { Continual } \\
\text { Continual }\end{array}$ \\
\hline $\begin{array}{l}\text { Rhododendron myrtifolium } \\
\text { Pozhyzhevska, 1700, NW } \\
\text { Komanova, 1700, NE } \\
\text { Steryshora, } 1450, \mathrm{NE} \\
\text { Syniak, } 1650, \mathrm{~N}, \mathrm{~S}\end{array}$ & $\begin{array}{l}\text { Reservation } \\
\text { State border regime } \\
\text { Grazing } \\
\text { Trampling }\end{array}$ & $\begin{array}{c}3.3 \pm 0.5 \\
2.6 \pm 0.3 \\
1.7 \pm 0.1 \\
0.06 \pm 0.01\end{array}$ & $\begin{array}{l}\text { Continual } \\
4000 \\
2500 \\
1200\end{array}$ \\
\hline $\begin{array}{l}\text { Senecio carpaticus } \\
\text { Petros, 1980, E } \\
\text { Rebra, 1900-2000, SW } \\
\text { Pozhyzhevska, 1760, NE }\end{array}$ & $\begin{array}{l}\text { Grazing } \\
\text { Grazing } \\
\text { Reservation }\end{array}$ & $\begin{array}{c}3.1 \pm 0.4 \\
6.8 \pm 1.0 \\
17.5 \pm 2.0\end{array}$ & $\begin{array}{l}1000 \\
\text { Continual } \\
340\end{array}$ \\
\hline
\end{tabular}

ISSN 1996-4536 (print) • ISSN 2311-0783 (on-line) • Біологічні Студії / Studia Biologica • 2015 • Том 9/№2 • С. 169-180 
Progressive changes of Rhododendron myrtifolium (RDB) populations, Carpathian-Balkan species, are marked both in alpine communities of protected territories and in those, that have undergone significant transformations due to pastoral activity (see Table). In particular on such disturbed sites, Rhododendron myrtifolium takes one of the principal positions in course of intensive plant cover restoration.

Single locality species. Natural restoration of rare species Callianthemum coriandrifolium is observed at Mt. Brebeneskul (Chornohora) - the only one locality known in the Ukrainian Carpathians [4]. During 1995-2013 number of individuals increased from 680 to over 2500 , as well as total density from $3.1 \mathrm{ind} . / \mathrm{m}^{2}$ to $11.8 \mathrm{ind} . / \mathrm{m}^{2}$ and percentage of flowering plants - from $7.1 \%$ to $40.2 \%$. Contours of three "primary" loci gradually converged during this period. Recreation is the main threat to this population. Hiking trail crosses the habitat, therefore nearby plants are being trampled heavily during the vegetation period and consequently the absolute individual parameters decrease [14].

Populations of rare and common species, such as alpine species Oreochloa disticha and Carex curvula, have regressed during the last years. Isolated Carex curvula populations at the lower altitudinal limit of distribution (Chornohora, Mt. Drabyny, $1850 \mathrm{~m}$ a.s.I.) are rapidly degrading. For the past 10 years (since 2003) the decrease in numbers and area, as well as aging of population from normal left-side with a full age spectrum to regressive incomplete without middle-aged flowering individuals of high viability, occurred. Mortality was marked at all age stages. Decline in viability of Carex curvula populations is observed throughout the Chornohora range and the largest site on Mt. Brebeneskul in particular. Remarkably, Carex curvula is being replaced with an expanding species Loiseleuria procumbens there.

Populations of the alpine species Carex curvula and Oreochloa disticha at the lower altitudinal limit of distribution are currently under the negative influence of global warming. At the same time the Oreochloa disticha population (Mt. Turkul) is degrading because of man-induced pressure. As a consequence of hard trampling of herbal cover to bare soil and other impacts of recreation, in 2014 the part of the population near the mountain summit was completely eliminated. The peripheral part of the Oreochloa disticha population survived $15-20 \mathrm{~m}$ down slope, where recreation influence is insignificant.

Subalpine meadows. Since 1995-1997 grazing in subalpine meadows in the Chyvchyny Mts. has ceased or it intensity decreased significantly in some minor parts [8]. As a result of restoration of natural vegetation, the only known large population of the EastCarpathian endemic Heracleum carpaticum emerged. Other populations of this species are smaller and have a lower number. The total area of population loci is approximately $3000 \mathrm{~m}^{2}$ and they are located on the territory of 9 ha. The population is normal, full spectrum, has high viability and efficient numbers up to 4 thousand individuals.

Endemic Galium pawlowskii is a range-margin species in the Chyvchyny Mts. As a result of rapid transformation of natural biotopes the colonizing strategy of the populations is changing from "phalange" to "guerrilla" when interspecies competition increases. The morphometric characteristics of flowering shoots increase and the proportion between vegetative and generative ones moves in favor of latter. Under the overgrazing on some mountain grasslands near the settlements populations express negative dynamics, and have all the features of pasture degradation.

ISSN 1996-4536 (print) • ISSN 2311-0783 (on-line) • Біологічні Студії / Studia Biologica • 2015 • Том 9/№2 • C. 169-180 
Plant populations of Rhodiola rosea, Antennaria carpatica, Dianthus carpaticus ihabit the open rock high-mountain communities (due to the patchy distribution and isolation) are vulnerable to both natural and man-induced factors. Negative trends in population structure of these species occur because of periodical gathering with decorative or medical purpose. Simultaneously with man-induced impact negative trends in populations are associated with their response to warming at recent time period. In particular it refers cold resistant arctic-alpine species Rhodiola rosea, Antennaria carpatica. Stress disturb the population structure: spatial and sexual, and reduce the seed reproduction [3]. In the consequence, the structural integrity of populations is disturbed, disintegration to separate fragments occurs. Trends of negative dynamics in Rhodiola rosea population structure for the period 2003-2013 is displayed in Fig. 4. The reduction of individual numbers, especially of the flowering ones, and their phytomass and variability is the characteristic feature of population pattern changes. It is confirmed by small annual growth and reduction of rhizome thickness. The indicators of individual development: metrical, morphological and rhythmological, demonstrate almost 2-fold decrease. Abrupt fall of flowering individuals' numbers impede the population restoration ability and seed recruitment. Development of individuals is accompanied by prolonged pregenerative period, gap of generative stage and change of the life form. The process of individual regeneration slows down, that is the characteristic feature. Their development is possible because of activation of dormant buds on rhizome. Trends of negative dynamics in species populations are followed by stronger insularisation, area and diversity decrease. This is accompanied with changes in structural organization of populations (spatial, sexual, reproductive) and viability reduction.

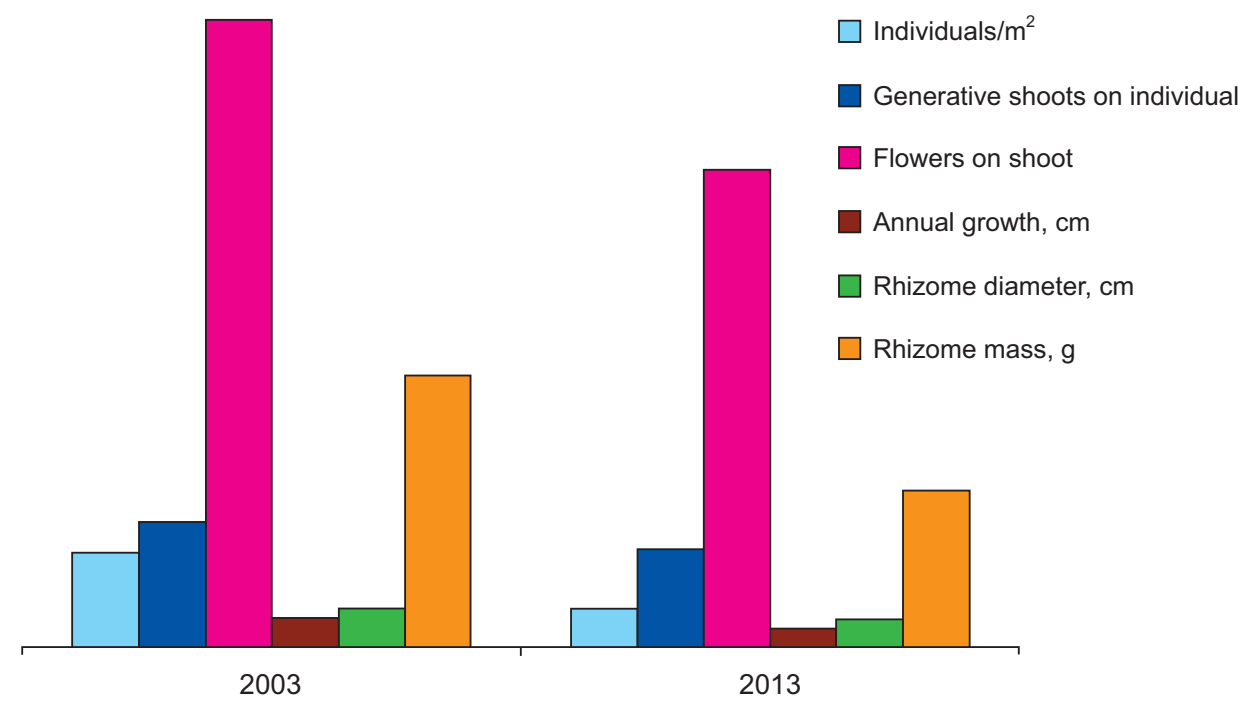

Fig. 4. Changes of population characters of Rhodiola rosea L. at Chornohora mts. (2003-2013)

Рис. 4. Зміни популяційних показників Rhodiola rosea L. у Чорногорі (2003-2013)

Timberline. The distribution of endemic species Pulmonaria filarszkyana is connected with endemic association: Pulmonario-Alnetum viridis Pawi. et Wal. 1949 corr.

ISSN 1996-4536 (print) • ISSN 2311-0783 (on-line) • Біологічні Студії / Studia Biologica • 2015 • Том 9/№2 • С. 169-180 
Kricsfalusy et Malynovski 2000 with Alnus viridis, Cirsium waldsteinii Rouy, Rumex alpestris subsp. carpaticus Zapai. [10]. This species is included in international and regional lists of protected species. In the Ukrainian Carpathians the habitats of Pulmonaria filarszkyana are known in Chornohora, Svidovets, Chyvchyny, Marmaros Mts. In general, many large localities are discovered. Within the range of Pulmonaria filarszkyana in the Ukrainian Carpathians it is possible to distinguish 3 types of population and subpopulation groups, which differ by a set of group parameters, location, size, number, way of recovery and degree of isolation: "mainland" populations, local populations and isolated subpopulation formations [1].

At the subalpine belt of the Carpathians Pulmonaria filarszkyana successfully occupies its community positions because of stable vegetative propagation and periodic seed reproduction within inhabited loci. However, elimination or destruction (for different reasons) of green alder canopy provoke the increase of the cover of firm bunchgrasses. As a result, the appearance of unfavorable loci for seed and vegetative reproduction the population of Pulmonaria filarszkyana disintegrates into separated fragments.

Under the climate and/or man-induced impact upper and lower elevation limits of species distribution in the Ukrainian Carpathians are constantly changing. As a result of ecological and plant community changes in the peripheral zones the population numbers and density decline with following population fragmentation. At the subalpine zone under the intensive grazing and raise of spruce forest timberline isolated habitats disappear completely or are represented by single individuals. Despite of the low viability and lack of seed recruitment such habitats in the case of conservation of initial environmental parameters may become the population renewal centers. It is possible to consider, that the size of whole population and some local populations fluctuate over the years. Their numbers and occupied area display similar fluctuations. Population dynamics correlate with the climate, ecological and plant community changes (Fig. 3).

According to long-term investigations of snowbed communities, the direct maninduced impact does not have influenced significantly the plant populations. The reason is that the habitats are remote from tourist routes. The climate change is the determinant factor of the environmental impacts and the weather sharp fluctuations. In 20082013 the reduction of snow cover thickness in winter (Fig. 2), the rise of air temperature and decrease of precipitation during the vegetative period (Fig. 3) were observed. Reduction of duration of snowfields because of insignificant snow accumulation and warming in the studied ecotopes, eliminates habitat sustainable water supply and makes them dependent on weather conditions, particularly precipitation. Changes in cover, ontogeny, age and spatial structure are the manifestation of the influence of the abovementioned drivers on the population pattern. Lack of soil moisture, when seedlings emerge, is one of the reasons for increased mortality of pregenerative individuals and results in the aging of populations of Veronica alpina, Luzula spadicea, Gnaphalium supinum, Saxifraga carpatica, Dichodon cerastoides. The ontogeny of Saxifraga carpatica and Veronica alpina reduces in these conditions. At the periphery of the habitats cover and density have decreased in Dichodon cerastoides, Saxifraga carpatica, Veronica alpina (Fig. 5). At the same time, total cover of the major keystone species increased twice in the central parts of the habitats.

ISSN 1996-4536 (print) • ISSN 2311-0783 (on-line) • Біологічні Студії / Studia Biologica • 2015 • Том 9/№2 • C. 169-180 


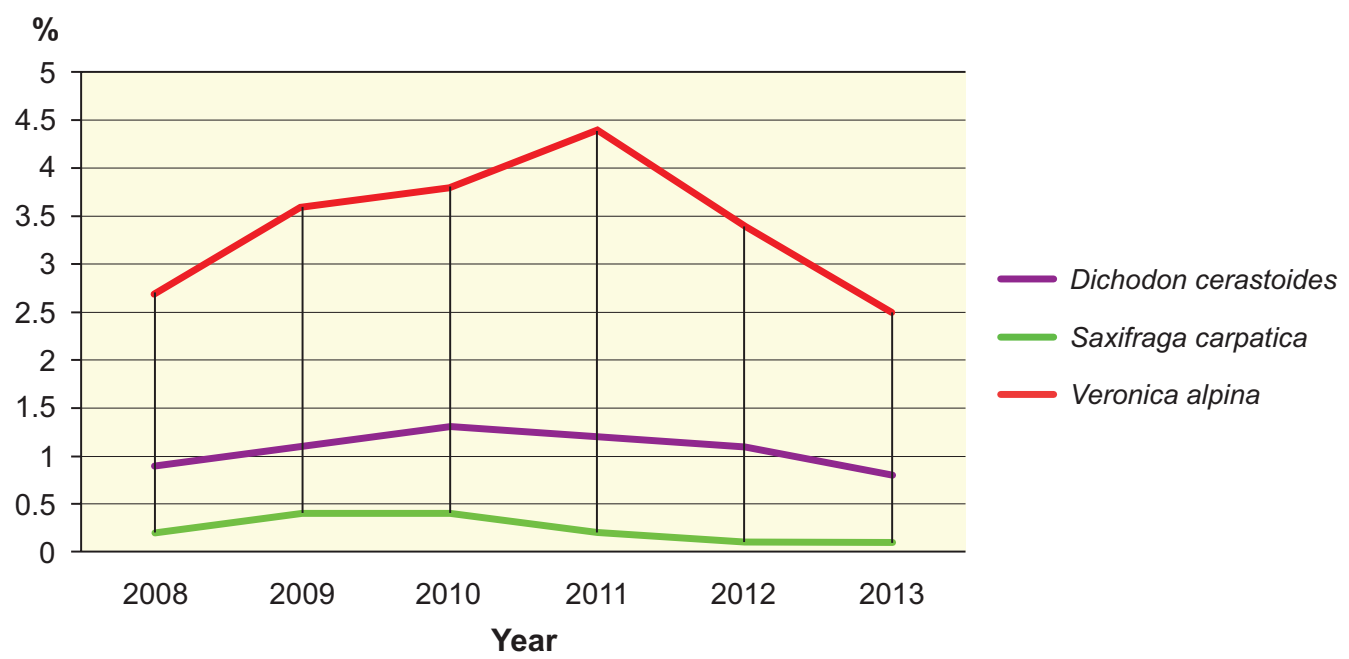

Fig. 5. Projective cover changes of Dichodon cerastoides (L.) Rchb., Saxifraga carpatica Sternb. and Veronica alpina L. at periphery of snowbed community (Mt. Brebeneskul N-E slope 1,900 m a. s. I.)

Рис. 5. Зміни проективного покриття Dichodon cerastoides (L.) Rchb., Saxifraga carpatica Sternb. i Veronica alpina L. на периферії хіонофільного угруповання (г. Бребенескул, пн.-сх., 1900 м н.р.м.)

\section{CONCLUSIONS}

Nowadays, on large high-mountain territories of the Ukrainian Carpathians, the population area, numbers and density of trees, shrubs and dwarf shrubs - Picea abies, Pinus mugo, Alnus viridis, Juniperus sibirica, Rhododendron myrtifolium, the Vaccinium-species actively increase.

During recent years, the flowering and fruit maturation even at higher elevations of alpine mountain belt are characteristic for Vaccinium myrtillus, Centaurea mollis, Homogyne alpina, Helictotrichon versicolor, Potentilla aurea. This trend is related with warming and prolongation of growing season and is peculiar for the species with ecological and climate optima in the forest and subalpine belts, whereas the conditions of the alpine belt are extreme for them.

Rare and endemic plant species' populations: Loiseleuria procumbens, Senecio carpaticus, Heracleum carpaticum, Rhododendron myrtifolium, Callianthemum coriandrifolium, Galium pawlowskii are expanding. However, the alpine and arctic-alpine species: Carex curvula, Dichodon cerastoides, Oreochloa disticha, Rhodiola rosea, Saxifraga carpatica demonstrate negative dynamics, as well as rare Antennaria carpatica.

The described processes are mainly a result of successions and plant cover restoration due to grazing termination and climate warming. The impact of plant cover restoration and raising of timberline on the populations of investigated species at high mountain zone of protected areas often cannot be separated from the impact of global warming. The reproductive parameters of the individuals and populations, as the most sensitive to impact of the environment, indicate the plant population pattern changes.

ISSN 1996-4536 (print) • ISSN 2311-0783 (on-line) • Біологічні Студії / Studia Biologica • 2015 • Том 9/№2 • С. 169-180 
1. Bilonoha V. Spatial structure of Pulmonaria filarszkyana Jáv. in Ukrainian Carpathians. Proc. of the State Nat. Hist. Museum. Lviv, 2011, 27: 63-70. (In Ukrainian).

2. Didukh Y. Ecological aspects of the global climate changes: reasons, consequences and actions. Bulletin of the National Academy of Sciences of Ukraine, 2009; 2: 34-44. (In Ukrainian).

3. Dmytrakh R. Recruitment of populations of the heterosexual species in different natural and anthropogenic conditions. Sc. Bull. UNFU, 2012; 22(13): 76-81. (In Ukrainian).

4. Gonzalez A., Rayfield B., Lindo Z. The disentangled bank: how loss of habitat fragments and disassembles ecological networks. American Journal of Botany, 2011; 98(3): 503-516.

5. Gynda L.V., Pochynok T.V. Variability evaluation of the systematic characters of Centaurea mollis Waldst. et Kit. and C. marmarosiensis (Jáv.) Czer. Proc. of the State Nat. Hist. Museum. Lviv, 2009; 25: 233-238. (In Ukrainian).

6. Klanderud $K$. Species-specific responses of an alpine plant community under simulated environmental change. Journal of Vegetation Science, 2008; 19: 363-372.

7. Kobiv Y.Y., Nesteruk Y.Y. Unique population of Callianthemum coriandrifolium Reichenb. (Ranunculaceae) in the Chornohora (Ukrainian Carpathians). Ukr. Botan. J, 1996; 53(3): 18-223. (In Ukrainian).

8. Kobiv Y., Prokopiv A., Helesh M. et al. Distribution and state of populations of rare, endangered and endemic species of plants in the nothern part of frontier area in the Chyvchyny mountains (Ukrainian Carpathians). Visnyk of Lviv University. Biolog. Ser, 2007; 45: $71-$ 84. (In Ukrainian).

9. Kyyak V. Small population of rare plant species in highlands of the Ukrainian Carpathians. Lviv: Lviv-Press, 2013. 248 p. (In Ukrainian).

10. Malynovski K., Kricsfalusy V. Plant communities of the Ukrainian Carpathian highlands. Uzhgorod, 2002. 244 p. (In Ukrainian).

11. Malinovski K., Tsaryk Y., Zhilyaev G. et al. Population structure of rare species of Carpathian flora. Kyiv: Naukova Dumka, 1998.176 p. (In Ukrainian).

12. Malinovski K., Tsaryk Y., Kyyak V., Nesteruk Y. Rare, endemic, relict and marginallyranged plant species of the Ukrainian Carpathians. Lviv: Liga-Press, 2002. 76 p. (in Ukrainian),

13. Tsaryk Y., Zhilyaev G., Kyyak V. et al. Intrapopulation diversity of rare, endemic and relict plant species of the Ukrainian Carpathians. Lviv: Polli, 2004.198 p. (lin Ukrainian).

14. Tsaryk Y., Zhilyaev G., Kyyak V. et al. Viability of plant populations of high-mountain zone of the Ukrainian Carpathians. Lviv: Mercator, 2009. 172 p. (In Ukrainian).

15. Tsaryk Y., Zhilyaev G., Kyyak $V$. et al. The mechanisms of self-renewal of populations. Lviv: Spolom, 2014. 216 p. (In Ukrainian).

16. Tsaryk Y., Malinovski K., Zhilyaev G. et al. Strategy of plants populations in natural and anthropogenic changed ecosystems of the Carpathians. Lviv: Evrosvit, 2001.160 p.

17. Walther G.R., Beißner S., Pott R. Climate change and high mountain vegetation. In: Broll G., Keplin B. (Eds.). Mountain Ecology. Studies in Treeline Ecology. Berlin: Springer, 2005: 77-96.

ISSN 1996-4536 (print) • ISSN 2311-0783 (on-line) • Біологічні Студії / Studia Biologica • 2015 • Том 9/№2 • С. 169-180 


\title{
ТЕНДЕНЦІї ЗМІН СТРУКТУРИ ПОПУЛЯЦІЙ РОСЛИН ВИСОКОГІР'Я УКРАЇНСЬКИХ КАРПАТ ПІД ВПЛИВОМ ПРИРОДНИХ I АНТРОПОГЕННИХ ЧИННИКІВ
}

\author{
В. Г. Кияк', В. М. Білонога², Р. І. Дмитрах ${ }^{2}$, \\ Л. В. Гинда', Ю. Й. Нестерук' , В. П. Штупун \\ 1 Львівський національний університет імені Івана Франка \\ вул. Грушевського, 4, Львів 79005, Україна \\ ${ }^{2}$ /нститут екології Карпат НАН України, вул. Козельницька, 4, Львів 79026, Україна \\ e-mail: lusikagynda@gmail.com
}

У високогір”ї Українських Карпат істотно збільшується площа, чисельність, щільність і життєвість популяцій деревних, чагарникових та чагарничкових видів, зокрема, Picea abies, Pinus mugo, Alnus viridis, Juniperus sibirica, Rhododendron myrtifolium, видів роду Vaccinium.

Для низки видів різних життєвих форм (Vaccinium myrtillus, Centaurea mollis, Homogyne alpina, Helictotrichon versicolor, Potentilla aurea) притаманне цвітіння і визрівання плодів на дедалі більших висотних рівнях альпійського поясу. Це характерне у зв'язку з потеплінням і збільшенням тривалості вегетаційного періоду для тих видів, для яких еколого-кліматичний оптимум розташований у лісовому або субальпійському поясі, а умови альпійського поясу є екстремальними.

Виявлено рідкісні й ендемічні види рослин, популяції яких прогресують, а саме: Loiseleuria procumbens, Senecio carpaticus, Heracleum carpaticum, Rhododendron myrtifolium та ін. Негативна динаміка притаманна високогірним альпійським і арктоальпійським видам, зокрема, Oreochloa disticha, Rhodiola rosea, Carex curvula та ін.

Описані процеси зумовлені в основному як демутаційними сукцесіями внаслідок припинення випасу, так і потеплінням клімату. Важливо встановити диференціацію впливу цих чинників на види і популяції. Найсильніше змінюються репродуктивні параметри особин і популяцій як найбільш чутливі до змін навколишнього середовища.

Ключові слова: популяції рослин, високогір'я Українських Карпат, популяційні характеристики, зміни клімату.

\section{ТЕНДЕНЦИИ ИЗМЕНЕНИЙ СТРУКТУРЫ ПОПУЛЯЦИЙ РАСТЕНИЙ ВЫСОКОГОРЬЯ УКРАИНСКИХ КАРПАТ ПОД ВЛИЯНИЕМ ЕСТЕСТВЕННЫХ И АНТРОПОГЕННЫХ ТРАНСФОРМАЦИЙ}

\author{
В. Г. Кияк', В. М. Билонога², Р. И. Дмытрах \\ Л. В. Гинда², Ю. И. Нестерук', В. П. Штупун \\ ${ }^{1}$ Львовский национальный университет имени Ивана Франко \\ ул. Грушевского, 4, Львов 75005, Украина \\ e-mail: lusikagynda@gmail.com
}

${ }^{2}$ Институт экологии Карпат НАН Украины, ул. Козельницкая, 4, Львов 79026, Украина

На высокогорье Украинских Карпат существенно увеличивается площадь, численность, плотность и жизненность популяций древесных, кустарниковых и кустарничковых видов, а именно Picea abies, Pinus mugo, Alnus viridis, Juniperus

ISSN 1996-4536 (print) • ISSN 2311-0783 (on-line) • Біологічні Студії / Studia Biologica • 2015 • Том 9/№2 • С. 169-180 
sibirica, видов рода Vaccinium L. Для ряда видов разных жизненных форм (Vaccinium myrtillus, Centaurea mollis, Homogyne alpina, Helictotrichon versicolor, Potentilla aurea) свойственны цветение и созревание плодов на все больших высотных уровнях альпийского пояса. Это характерно в связи с потеплением и увеличением продолжительности вегетационного периода для тех видов, для которых экологоклиматический оптимум размещен в лесном или субальпийском поясе, а условия альпийского пояса - экстремальны. Обнаружены редкие и эндемические виды растений, популяции которых прогрессируют, а именно: Loiseleuria procumbens, Senecio carpaticus, Heracleum carpaticum, Rhododendron myrtifolium и др. Негативная динамика свойственна высокогорным альпийским и аркто-альпийским видам, особенно Oreochloa disticha, Rhodiola rosea, Carex curvula и др. Описанные процессы обусловлены в основном как демутационными сукцессиями вследствие прекращения выпаса, так и потеплением климата. Важно установить диффреренциацию влияния этих фракторов на виды и популяции. Наиболее изменчивы репродуктивные параметры особей и популяций как самые чувствительные к изменениям окружающей среды.

Ключевые слова: популяции растений, высокогорье Украинских Карпат, популяционные характеристики, изменения климата.

Одержано: 15.06.2015

ISSN 1996-4536 (print) • ISSN 2311-0783 (on-line) • Біологічні Студії / Studia Biologica • 2015 • Том 9/№2 • C. 169-180 